\title{
Return of Cultural Treasures to Germany
}

\author{
Kurt Siehr*
}

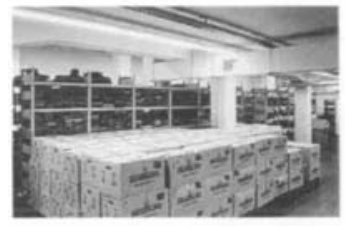

German books returned by the Republic of Georgia.

(C) State Library of Berlin
It is now common knowledge that thousands of cultural objects were taken by the Russian army and Russian soldiers out of Germany during and after World War II. For forty years these objects were hidden somewhere in the Soviet Union until their storage was revealed after the end of the Cold War.'

In treaties on cultural cooperation concluded by Germany with the Soviet Union and with the successor states of the Soviet Union, the contracting states agreed to return missing or unlawfully removed cultural objects to the owner or its legal successor. ${ }^{2}$ So far Russia has declined to return the cultural objects of German provenance. It rather exhibited them in Moscow or St. Petersburg. ${ }^{3}$

In contrast to this attitude, in August 1996 the Republic of Georgia returned to Germany 100.000 books taken from German libraries, and the Government of Ukraine and the Government of the Federal Republic of Germany returned cultural objects according to the annexed protocols of 3 September 1996.

\section{Notes}

1 Akinsha \& Kozlov, Beautiful loot. The Soviet Plunder of Europe's ART Treasures (New York 1995).

2 See, e. g., Article 16 of the German-Ukrainian Treaty, infra at note 1 of the annexed protocols.

3 The treasure of Troy has been on exhibit in Moscow (since April 1996), the Gerstenberg and Krebs Collections of Impressionist paintings in St. Petersburg (1995), the collection Franz Koenigs in Moscow (2 October 1995-21 January 1996), and the Master Pieces of European Drawings from German Private Collections in St. Petersburg (December 1996 - March 1997).

* Professor of Law, University of Zürich. 